\title{
Optimal Exchange-Rate Policy in a Model of Local-Currency Pricing with Vertical Production and Trade
}

\author{
Liutang Gong ${ }^{1}$. Chan Wang ${ }^{1} \cdot$ Heng-fu Zou Zu, $^{2,4}$
}

Published online: 14 September 2016

(C) Springer Science+Business Media New York 2016

\begin{abstract}
In this paper, we examine optimal exchange-rate flexibility in a model of local-currency pricing with vertical production and trade. Following a large body of empirical evidence, we assume that final-goods prices are sticky, but intermediategoods prices are flexible. We find that, unlike what is found in the literature, optimal nominal exchange rate is flexible under local-currency pricing. The key element in deriving our conclusion is the difference in expenditure shares between home and foreign households. The conclusion holds even if the degrees of home bias in production are identical between home and foreign final-goods producers, which contrasts with the findings in the literature.
\end{abstract}

Keywords Optimal monetary policy $\cdot$ Local-currency pricing $\cdot$ Vertical production and trade $\cdot$ Exchange-rate policy

JEL Classification E5 $\cdot$ F3 $\cdot$ F4

Chan Wang

wangchanist@126.com

Liutang Gong

ltgong@gsm.pku.edu.cn

Heng-fu Zou

Hzoucema@gmail.com

1 Guanghua School of Management and LMEQF, Peking University, Beijing 100871, China

2 China Economics and Management Academy, Central University of Finance and Economics, Beijing 100081, China

3 Institute for Advanced Study, Wuhan University, Wuhan 430072, China

4 Institute for Advanced Study, Shenzhen University, Shenzhen 518060, China 


\section{Introduction}

What is the optimal exchange-rate flexibility? The answer to this question is at the heart of international monetary economics. Friedman (1953) argues for freely floating exchange rates. ${ }^{1}$ The reason is, when nominal goods prices are sticky, flexible exchange rates can deal with real country-specific productivity or demand shocks. By comparison, many policy makers and academic researchers believe that exchange rate stability can increase the volume of trade and welfares. The 1990 European Community report "One market, one money" advocating the adoption of one currency in Europe is based on the belief that increased trade will benefit the Europe. The creation of the euro in 1999 is the real child of the belief.

Appealing as the argument, Friedman's reasoning lacks microfoundation for intertemporal choice. Likewise, the argument for stable nominal exchange rates to increase the volume of trade and welfares also lacks a sound theoretic foundation. More recently, by combining intertemporal choice and nominal rigidities, Obstfeld and Rogoff (2000, 2002) lay the foundations for the analysis of optimal exchange-rate flexibility in a two-country New Keynesian monetary model. In Obstfeld and Rogoff (2000, 2002), they assume that exporting firms set prices in their own currency (producer-currency pricing or PCP), ${ }^{2}$ accordingly, optimal monetary policy requires the nominal exchange rate to be flexible to replicate the flexible price allocation. Empirical evidence, however, questions producer-currency pricing and resultant rapid, complete exchange-rate pass-through and suggests that exporting firms price discriminate among markets and set prices in the consumers' currency (local-currency pricing or LCP). ${ }^{3}$ Unlike the case of PCP, the exchange-rate pass-through in LCP case is incomplete when exporting firms' price adjustment is sluggish. It is interesting to explore the optimal exchange-rate flexibility in LCP case both for policy practice and academic research.

As far as we know, Betts and Devereux (2000) first introduce international market segmentation and local-currency pricing into the dynamic two-country model of Obstfeld and Rogoff (1995) to discuss exchange rate dynamics. ${ }^{4}$ In Obstfeld and Rogoff (1995), and Betts and Devereux (2000), the nominal exchange rate responds to unanticipated home and foreign money and government spending shocks thus is flexible. However, in Betts and Devereux (2000), international market segmentation and local-currency pricing limit the pass-through from exchange rate changes to importing prices and reduce the expenditure-switching role played by exchange rate changes. Accordingly, compared with Obstfeld and Rogoff (1995), the presence of international market segmentation and local-currency pricing increases exchange rate volatility. But the deterministic environment in Obstfeld and Rogoff (1995), and Betts and Devereux (2000) makes it impossible to analyze optimal monetary

\footnotetext{
${ }^{1}$ For a recent review of Friedman's monetary policy proposals, see Tavlas (2015).

${ }^{2}$ In fact, implicitly, Friedman's conclusion is based on the same assumption.

${ }^{3}$ There is a substantial literature on the topic, See Engel (1999), Betts and Devereux (2000), and Atkeson and Burstein (2008), these papers cite many relevant papers.

${ }^{4}$ In Obstfeld and Rogoff (1995), exporting firms set prices in producers' currency one period in advance.
} 
policy, thus optimal exchange-rate flexibility. Obstfeld and Rogoff (2000, 2002) extend Obstfeld and Rogoff (1995) to a stochastic environment in which monetary policy rule in each country is chosen endogenously by monetary authority to maximize the expected utility of the representative household in its own country. As mentioned previously, in Obstfeld and Rogoff (2000, 2002), optimal monetary policy requires the exchange rate to be flexible to replicate the terms of trade in flexible price equilibrium. Consequently, the flexible price allocation can be achieved.

However, Devereux and Engel (2003), and Corsetti and Pesenti (2005) show that the prescription for flexible exchange rates by Friedman (1953), and Obstfeld and Rogoff (2000, 2002) depends crucially on exporting firms' currency choice. When exporting prices are set in local currency, Devereux and Engel (2003), and Corsetti and Pesenti (2005) conclude that optimal monetary policy can not replicate the terms of trade, thus the flexible price allocation. Furthermore, in their models, optimal monetary policy is to keep the nominal exchange rate fixed. Therefore, their result favors the stability of the nominal exchange rate and questions the traditional opinion of the costs of the currency union.

In this paper, we continue the discussion of the optimal exchange-rate flexibility and demonstrate that the flexible exchange rate is optimal in a monetary model with LCP. ${ }^{5}$ Our model is a modification to Devereux and Engel (2003). Different from Devereux and Engel (2003), we abstract from dynamics and only focus on a single period. The extension of the current model to an infinite horizon setting as in Devereux and Engel (2003) is straightforward and the conclusions still hold in the dynamic model. ${ }^{6}$ In addition, empirical evidence finds that more and more countries are trading not only in final consumption goods but also a large quantity of intermediate inputs (Bridgman 2012; Feenstra 1998; Hummels et al. 1998, 2001; Johnson 2014; Yi 2003, 2010). Following the empirical findings, we incorporate vertical production and trade into Devereux and Engel (2003) and analyze the effect of international trade in intermediate inputs on optimal exchange-rate flexibility. In fact, Devereux and Engel (2007), Shi and Xu (2007), Pang and Tang (2014), Wang and Zou (2015), and Gong et al. (2016) analyze optimal monetary policy in an environment in which vertical production and trade is present. However, these authors do not consider the optimal exchange-rate flexibility in LCP case. In order to facilitate the understanding of the structure of our model, we introduce briefly vertical production and trade. In our model, there are two stages of production and trade. We take the home country as an example to illustrate vertical production and trade. At the stage of

\footnotetext{
${ }^{5}$ For other references on the similar topic, see Devereux et al. (2005), Duarte and Obstfeld (2008), Senay and Sutherland (2015). When exporters can endogenously choose the currency of price setting, Devereux et al. (2005) find that there are multiple equilibria. One equilibrium corresponds to PCP case in which the flexible exchange rate is optimal and another corresponds to LCP case in which the fixed exchange rate is optimal. By restricting monetary authorities to respond only to domestic shocks, only PCP equilibrium survives. Duarte and Obstfeld (2008) find that the flexible exchange rate is optimal in LCP case when they introduce nontradable consumption goods into Devereux and Engel (2003). When considering foreign monetary shocks, Senay and Sutherland (2015) find that, in LCP case, home country is better off to adopt the flexible exchange rate.

${ }^{6}$ The main reason lies in our assumptions: (1) a full set of state-contingent bond; (2) price setting being one period in advance.
} 
final-goods production, a continuum of firms input both home and foreign intermediate goods to produce differentiated goods, which are consumed by both home and foreign households. At the stage of intermediate-goods production, a continuum of firms use domestic labor to produce differentiated goods, which are used as inputs by home and foreign final-goods producers. In addition, we allow home bias in households' consumption choices and final-goods producers' production factor choices. Unlike Engel (2011) and Gong et al. (2016), we assume that the degrees of home bias in consumption are different between home and foreign households. Likewise, the degrees of home bias in home and foreign final-goods producers' production factor choices are also assumed to be different. In order to obtain model's closed-form solution, we follow many empirical studies and assume that final-goods prices are sticky and set prior to the realizations of shocks; intermediate-goods prices, however, are assumed to be flexible. ${ }^{7}$

To make a comparison between PCP and LCP cases, following Devereux and Engel (2003), we first analyze optimal monetary policy in PCP case and then in LCP case. In PCP case, we find that monetary responses to positive productivity shocks at the stage of final-goods production are the same as those in Devereux and Engel (2003). However, due to the presence of vertical production and trade, both home and foreign monetary authorities need to respond to a positive productivity shock at the stage of intermediate-goods production, regardless of the place where it originates from. Since intermediate-goods prices are flexible, the terms of trade at the stage of intermediate-goods production are efficient. Thus optimal monetary policy in PCP case is to keep the nominal exchange rate flexible to replicate the terms of trade at the stage of final-goods production. Accordingly, optimal monetary policy in PCP case can replicate the flexible price allocation.

In LCP case, we find that optimal monetary policy requires the nominal exchange rate to be flexible rather than fixed as obtained in Devereux and Engel (2003). When exporting prices are set in local currency one period in advance, the relative price of foreign final goods in terms of home final goods facing the households in one country is constant thus the expenditure-switching function of the exchange rate does not work. In this circumstance, optimal monetary policy can not replicate the terms of trade at the stage of final-goods production. Accordingly, it is impossible for optimal monetary policy to replicate the allocation in the flexible price equilibrium. In a general case in which the degrees of home bias in consumption are not identical between home and foreign households, following a productivity shock regardless of the place where it originates from, the response of home consumption allocation is different from that of foreign consumption allocation. Therefore, in order to achieve perfect risk sharing, optimal monetary policy requires the exchange rate to be flexible to ensure that home and foreign households obtain identical marginal utilities from holding one unit of nominal stage-contingent bond in all states of the world.

\footnotetext{
${ }^{7}$ Among many others, Murphy et al. (1989) and Clark (1999) find that final-goods prices are significantly less volatile than intermediate goods; Bils and Klenow (2004) estimate that price flexibility of "raw goods" is about 3-4 times than that of processed goods; Nakamura and Steinsson (2008) also find that final-goods prices are less volatile than that of intermediate goods.
} 
By comparison, we obtain the result of Devereux and Engel (2003) as a special case in which the degrees of home bias in consumption are identical between home and foreign households. In their model, following a common productivity shock, home consumption makes the same response as foreign consumption. Thus, only in this special case does the exchange rate not need to be flexible to ensure perfect risk sharing between home and foreign households.

In addition, we find that our conclusion does not depend on the assumption that the degrees of home bias in production are different between home and foreign finalgoods producers. Specifically, even if the degrees of home bias in production are identical between home and foreign final-goods producers, the exchange rate is flexible when the degrees of home bias in consumption are not identical between home and foreign households. Thus our conclusion contrasts with Devereux and Engel (2007). In Devereux and Engel (2007), when all intermediate goods are traded and the degrees of home bias in production are identical between home and foreign final-goods producers, the fixed exchange rate is optimal. ${ }^{8}$ The reason is that the flexibility of intermediate-goods prices can achieve the desired terms of trade adjustment without movements in the exchange rate. However, their conclusion depends on the assumption that final consumption goods are nontradable. Thus any exchange rate movement would lead to a departure from optimal risk sharing. Comparing with Devereux and Engel (2007), our model is more general. In our model, all final consumption goods are tradable, in addition, the degrees of home bias in consumption and production are not identical between home and foreign countries. Thus, though flexible intermediate-goods prices can still achieve the desired terms of trade adjustment at the stage of intermediate-goods production with no movements in the exchange rate, a flexible exchange rate is needed to achieve optimal risk sharing at the stage of final-goods production.

The paper is organized as follows. Section 2 presents the model and solves for the flexible price solution. Section 3 derives optimal monetary policy rules and analyzes their implications for exchange-rate policy in both PCP and LCP cases. Section 4 concludes.

\section{The Model}

The world economy consists of two countries, home $H$ and foreign $F$, each of which is populated by a continuum of households of unit mass $[0,1]$. The production, both in the home and foreign countries, is integrated by two stages. At the stage of final-goods production, a continuum of home final-goods producers indexed by $j_{f} \in[0,1]$ input both home and foreign intermediate goods to produce final consumption goods, which are then consumed by both home and foreign households. At the stage of intermediate-goods production, a continuum of home intermediate-goods producers indexed by $j_{i} \in[0,1]$ employ domestic labor to produce differentiated

\footnotetext{
${ }^{8}$ See case 1 of Devereux and Engel (2007) which corresponds to the same setting as in our model, i.e. sticky final-goods prices, flexible intermediate-goods prices.
} 
products, which are used as inputs by both home and foreign final-goods producers. The foreign country has a symmetric production and trade structure.

As mentioned in the introduction, many empirical studies have found that the degree of price stickiness at the different stages of production is different. Following the literature, we assume that final-goods prices are sticky and set prior to the realizations of shocks; intermediate-goods prices, however, are assumed to be flexible.

As in Devereux and Engel (2003), we consider two alternative specifications for the pricing of tradable goods. ${ }^{9}$ The first specification involves exporting firms at both stages setting prices in their own currency (producer-currency pricing or PCP). In the second specification, exporting firms at both stages price discriminate among international markets, and set prices in the consumers' currencies (local-currency pricing or LCP). The focus of the present paper is on exchange-rate policy in LCP case, we provide the analysis in PCP case as a comparison.

Multi-period dynamics are not central to our conclusions, so we focus on a single period which is divided into two sub-periods by productivity shocks. ${ }^{10}$ In the first sub-period, households trade in a full set of state-contingent bonds denominated in the home currency, then monetary authorities announce monetary policy rules to the public, sticky-price firms set prices. In the second sub-period, flexible-price firms set prices, production inputs are employed, outputs are produced, households supply labor and choose consumption, and the exchange rate is determined. Throughout the period, we assume that monetary authorities are able to commit to the announced monetary policy rules.

In the following, asterisks denote foreign variables, subscript $f$ denotes the final good, and $i$ denotes the intermediate good.

\subsection{Households}

The expected utility of a home representative household is

$$
U=E\left[\ln C+\chi \ln \frac{M}{P}-\eta L\right],
$$

in which $\frac{M}{P}$ is the real money balances, $L$ is the labor supply, $\chi$ and $\eta$ are positive constant parameters. The real consumption index $C$ has an Armington form, $C=$ $\frac{C_{H}^{n} C_{F}^{1-n}}{n^{n}(1-n)^{1-n}}$, in which $n$ is the expenditure share of the home representative household on home final-goods subindex. When $n>1 / 2$, home households exhibit home-

\footnotetext{
${ }^{9}$ In Duarte and Obstfeld (2008), the representative household' consumption basket consists of nontradables as well as tradables. By comparison, in our model, both final consumption goods and intermediate goods in our model are tradable.

${ }^{10}$ As emphasized in Devereux et al. (2007), the assumptions of a complete set of state-contingent bonds and one-period price stickiness guarantee that the conclusions in the present paper can be carried over to an infinite-horizon model.
} 
bias in their consumption choices. Consumption subindexes $C_{H}$ and $C_{F}$ are defined respectively by

$$
C_{H}=\left[\int_{0}^{1} C_{H}\left(j_{f}\right)^{\frac{\lambda-1}{\lambda}} d j_{f}\right]^{\frac{\lambda}{\lambda-1}}, C_{F}=\left[\int_{0}^{1} C_{F}\left(j_{f}^{*}\right)^{\frac{\lambda-1}{\lambda}} d j_{f}^{*}\right]^{\frac{\lambda}{\lambda-1}}
$$

where $\lambda>1$ is the elasticity of substitution between varieties of final goods within each country, $j_{f} \in[0,1]$ denotes home final good $j, j_{f}^{*} \in[0,1]$ denotes foreign final good $j^{*}$. Foreign real consumption index has a similar form but the expenditure share of a foreign representative household on imported final-goods subindex is $n^{*}$. Thus, unlike Engel (2011) and Gong et al. (2016), we assume that the degrees of home-bias in consumption choices between home and foreign households are different.

The home CPI price index for overall real consumption index $C$ is

$$
P=\left(P_{H f}\right)^{n}\left(P_{F f}\right)^{1-n},
$$

in which $P_{H f}=\left[\int_{0}^{1} P_{H f}\left(j_{f}\right)^{1-\lambda} d j_{f}\right]^{\frac{1}{1-\lambda}}$ is the price index for home final goods sold in the home country, $P_{F f}=\left[\int_{0}^{1} P_{F f}\left(j_{f}^{*}\right)^{1-\lambda} d j_{f}^{*}\right]^{\frac{1}{1-\lambda}}$ is the price index for foreign final goods consumed by home households. The demands for goods $j f$ and $j_{f}^{*}$ by the home representative household can be derived as

$$
\begin{aligned}
C_{H}\left(j_{f}\right) & =n\left[\frac{P_{H f}\left(j_{f}\right)}{P_{H f}}\right]^{-\lambda}\left[\frac{P_{H f}}{P}\right]^{-1} C, \\
C_{F}\left(j_{f}^{*}\right) & =(1-n)\left[\frac{P_{F f}\left(j_{f}^{*}\right)}{P_{F f}}\right]^{-\lambda}\left[\frac{P_{F f}}{P}\right]^{-1} C .
\end{aligned}
$$

Similarly, foreign CPI price index is

$$
P^{*}=\left(P_{H f}^{*}\right)^{n^{*}}\left(P_{F f}^{*}\right)^{1-n^{*}},
$$

in which $P_{H f}^{*}\left(P_{F f}^{*}\right)$ denotes price subindex for home (foreign) final goods sold in the foreign country.

The home representative household faces the following budget constraint:

$$
P(z) C(z)+M(z)+\sum_{z^{\prime} \in Z} q\left(z^{\prime}\right) B\left(z^{\prime}\right)=W(z) L(z)+\Pi(z)+B(z)+M_{0}+T(z),
$$

where $z \in Z$ is a particular natural state, and $Z$ is the set of all states. $B\left(z^{\prime}\right)$ is the amount of bonds held by the household which entitles her to be paid $B$ units of home currency when state $z^{\prime}$ occurs, and $q\left(z^{\prime}\right)$ is the home currency price of the state-contingent bond, $W(z) L(z)$ is nominal wage income, $\Pi(z)$ represents profits from the ownership of home firms which distribute their profits among domestic households equally, $T(z)$ is lump-sum transfer from home government which rebates 
it's seigniorage revenue to home households equally, it means $M(z)-M_{0}=T(z)$, $M_{0}$ is initial holdings of nominal money balances.

Solving time-0 problem facing the home representative household, we can obtain the following first-order conditions:

$$
\begin{gathered}
M=\chi P C, \\
W=\eta P C, \\
\Gamma P C=S P^{*} C^{*} .
\end{gathered}
$$

Equation 3 is money demand function which implies that the marginal utility obtained by holding an extra unit of money is equal to the marginal cost measured by forgone current consumption; Eq. 4 describes optimal trade-off between leisure and consumption, which requires that the marginal rate of substitution between leisure and consumption is equal to the real wage; Eq. 5 is the risk-sharing condition between home and foreign households, which requires home and foreign households to equalize their marginal utilities from holding one unit of nominal stage-contingent bond in all states of the world. In Eq. 5, S is the nominal exchange rate which represents the home currency price of one unit of foreign currency, $\Gamma$ is the ratio of home and foreign households' Lagrange multipliers and is determined by an equilibrium condition in time- 0 market for state-contingent bonds. In general, $\Gamma$ is not equal to 1 to reflect the different positions between the home and foreign countries in the initial trading of state-contingent bonds. But as shown in the Appendix of Devereux and Engel (2003), when utility function of consumption is logarithmic, $\Gamma=1$ holds.

\subsection{Firms}

Home final goods are produced by a continuum of firms indexed by $j_{f} \in[0,1]$ with production function

$$
Y_{H f}\left(j_{f}\right)=\frac{\theta_{f} Y_{H i}\left(j_{f}\right)^{\varepsilon} Y_{F i}\left(j_{f}\right)^{1-\varepsilon}}{\varepsilon^{\varepsilon}(1-\varepsilon)^{1-\varepsilon}},
$$

in which $\theta_{f}$ is a home productivity shock at the stage of final-goods production, $Y_{H i}\left(j_{f}\right)$, the input of home intermediate composite which bundles differentiated home intermediate goods together, is defined as

$$
Y_{H i}\left(j_{f}\right)=\left[\int_{0}^{1} Y_{H i}\left(j_{f}, j_{i}\right)^{\frac{\phi-1}{\phi}} d j_{i}\right]^{\frac{\phi}{\phi-1}}, \phi>1 .
$$

$Y_{F i}\left(j_{f}\right)$, the input of foreign intermediate composite, has the same form as $Y_{H i}\left(j_{f}\right)$ but over varieties of foreign intermediate goods indexed by $j_{i}^{*} \in[0,1] . \varepsilon$ is the expenditure share of the firm $j_{f} \in[0,1]$ on home intermediate-goods aggregator. When $\varepsilon>1 / 2$, home final-goods producers display home-bias in the production.

In the foreign country, final goods are produced with a similar production function, but the expenditure share of the firm $j_{f}^{*} \in[0,1]$ on imported intermediate-goods aggregator is $\varepsilon^{*}$. Thus, unlike Devereux and Engel (2007) and Gong et al. (2016), 
we assume that the degrees of home-bias in production between home and foreign final-goods producers are different.

Solving cost minimization problem facing the home final-good producer $j_{f} \in$ $[0,1]$, we can obtain its unit cost function, which is $C\left(P_{H i}, P_{F i}\right)=\frac{P_{H i}^{\varepsilon} P_{F i}^{1-\varepsilon}}{\theta_{f}}$, in which $P_{H i}=\left[\int_{0}^{1} P_{H i}\left(j_{i}\right)^{1-\phi} d j_{i}\right]^{\frac{1}{1-\phi}}$ is home intermediate-goods PPI, $P_{F i}=$ $\left[\int_{0}^{1} P_{F i}\left(j_{i}^{*}\right)^{1-\phi} d j_{i}^{*}\right]^{\frac{1}{1-\phi}}$ is the price index for foreign intermediate goods used as inputs by home final-goods producers.

The expression for $Y_{H i}\left(j_{f}\right)$ implies that firm $j_{f}^{\prime} s$ demand for home intermediate $\operatorname{good} j_{i}$ is

$$
Y_{H i}\left(j_{f}, j_{i}\right)=\varepsilon\left(\frac{P_{H i}\left(j_{i}\right)}{P_{H i}}\right)^{-\phi}\left(\frac{P_{H i}}{C\left(P_{H i}, P_{F i}\right)}\right)^{-1} Y_{H f}\left(j_{f}\right) .
$$

Similarly, its demand for foreign intermediate $\operatorname{good} j_{i}^{*}$ is

$$
Y_{F i}\left(j_{f}, j_{i}^{*}\right)=(1-\varepsilon)\left(\frac{P_{F i}\left(j_{i}^{*}\right)}{P_{F i}}\right)^{-\phi}\left(\frac{P_{F i}}{C\left(P_{H i}, P_{F i}\right)}\right)^{-1} Y_{H f}\left(j_{f}\right) .
$$

At the stage of intermediate-goods production, differentiated intermediate goods are produced by a continuum of firms indexed by $j_{i} \in[0,1]$ with production function

$$
Y_{H i}\left(j_{i}\right)=\theta_{i} L\left(j_{i}\right) \text {, }
$$

where $\theta_{i}$ is a home productivity shock at the stage of intermediate-goods production, $L\left(j_{i}\right)$ is firm $j_{i}^{\prime} s$ labor input which is supplied by home households.

As evidenced by a large body of empirical literature, final-goods prices are more sticky than intermediate goods. We follow the literature and assume that prices at the stage of final-goods production are sticky but prices at the stage of intermediategoods production are flexible.

Solving for optimal prices is standard, thus we just list them in Table 1.

In LCP case, a firm chooses one price for the households in its own country and another price for the households in the other country. Take the home final-good producer as an example, it chooses $P_{H f}$ and $P_{H f}^{*}$ for the home and foreign households respectively before the realizations of shocks. Due to the market power over its differentiated product, the home final-good producer chooses $P_{H f}$ as a fixed mark-up

Table 1 Optimal prices in LCP case

$$
\begin{array}{ll}
\hline P_{H f}=\frac{\lambda}{\lambda-1} E\left(\frac{P_{H i}^{\varepsilon} P_{F i}^{1-\varepsilon}}{\theta_{f}}\right) & P_{H f}^{*}=\frac{\lambda}{\lambda-1} E\left(\frac{P_{H i}^{\varepsilon} P_{F i}^{1-\varepsilon}}{S \theta_{f}}\right) \\
P_{F f}=\frac{\lambda}{\lambda-1} E\left(\frac{S P_{H i}^{* \varepsilon^{*}} P_{F i}^{* 1-\varepsilon^{*}}}{\theta_{f}^{*}}\right) & P_{F f}^{*}=\frac{\lambda}{\lambda-1} E\left(\frac{P_{H i}^{* \varepsilon^{*}} P_{F i}^{* 1-\varepsilon^{*}}}{\theta_{f}^{* i}}\right) \\
P_{H i}=\frac{\phi}{\phi-1} \frac{W}{\theta_{i}} & P_{H i}^{*}=\frac{\phi}{\phi-1} \frac{W}{S \theta_{i}} \\
P_{F i}=\frac{\phi}{\phi-1} \frac{W^{*} S}{\theta_{i}^{*}} & P_{F i}^{*}=\frac{\phi}{\phi-1} \frac{W^{*}}{\theta_{i}^{*}}
\end{array}
$$


over its expected unit cost. ${ }^{11}$ Similarly, in the foreign country, it chooses $P_{H f}^{*}$ as a fixed mark-up over its expected unit cost expressed in the foreign currency. As a comparison, in PCP case, the home final-good producer chooses a single price in its own currency, which is identical to the price charged by it for the home households in LCP case, i.e. $P_{H f}$ in the top left-hand entry of Table 1 . The price for the foreign households, $P_{H f}^{*}$, by the law of one price, is just $P_{H f} / S$. Similarly, the foreign finalgood producer chooses $P_{F f}^{*}$ in the right-hand entry of the second row in the Table 1 for its own country's households. The price for the home households, by the law of one price, is $S P_{F f}^{*}$.

When prices are set one period in advance, the pass-through of the exchange rate is complete in PCP case, but it is zero in LCP case. However, when prices are flexible, the pass-through of the exchange rate is complete even if it is in LCP case. Thus, the home intermediate-good producer chooses $P_{H i}$ as a fixed mark-up over it real unit cost in its own country and $P_{H i}^{*}=P_{H i} / S$ in the foreign country.

Following Shi and $\mathrm{Xu}$ (2007), we assume that $\theta_{f}=\exp (u)$ and $\theta_{i}=\exp (v)$, in which $u$ and $v$ are normally distributed with zero mean and variance-covariance matrix

$$
\sum=\left(\begin{array}{cc}
\sigma_{u}^{2} & \sigma_{u v} \\
\sigma_{u v} & \sigma_{v}^{2}
\end{array}\right) .
$$

Foreign productivity shocks are also assumed to have the same properties. To keep calculations as simple as possible, we assume $\sigma_{u}^{2}=\sigma_{v}^{2}=\sigma_{u^{*}}^{2}=\sigma_{v^{*}}^{2}=\sigma^{2}, \sigma_{u v}=$ $\sigma_{u^{*} v^{*}}$ and $\sigma_{u u^{*}}=\sigma_{u v^{*}}=\sigma_{\nu v^{*}}=\sigma_{u^{*} v}=0$. Thus, $-\sigma^{2} \leq \sigma_{u v} \leq \sigma^{2}$ follows.

\subsection{The flexible-price equilibrium}

Before solving for the flexible-price solution, we need market-clearing conditions to close the model. Home market-clearing condition is given by

$$
\begin{aligned}
\theta_{i} L= & \varepsilon \frac{C\left(P_{H i}, P_{F i}\right)}{P_{H i}}\left(n \frac{P C}{P_{H f}}+n^{*} \frac{P^{*} C^{*}}{P_{H f}^{*}}\right)+ \\
& \varepsilon^{*} \frac{C^{*}\left(P_{H i}^{*}, P_{F i}^{*}\right)}{P_{H i}^{*}}\left((1-n) \frac{P C}{P_{F f}}+\left(1-n^{*}\right) \frac{P^{*} C^{*}}{P_{F f}^{*}}\right) .
\end{aligned}
$$

In Eq. 6, the first term on the right-hand side is the demands for home intermediate goods by home final-goods firms, the second term is the demands for home intermediate goods by foreign final-goods producers.

When prices are flexible at both stages of the production, all firms set prices after shocks are realized. A firm will set price on the basis of its real marginal cost adjusted by a markup to reflect its market power.

Flexible-price equilibrium consists of 17 equations: 8 pricing equations, 2 money demand equations, 2 labor supply equations, 2 CPI price indexes, 1 risk-sharing condition, 2 market-clearing conditions. There are 17 endogenous variables to be

\footnotetext{
${ }^{11}$ Note that the conclusion does not hold for a general CRRA consumption preference. For a detailed discussion, see Devereux and Engel (2003).
} 
determined: $P_{H f}, P_{H f}^{*}, P_{F f}, P_{F f}^{*}, P_{H i}, P_{H i}^{*}, P_{F i}, P_{F i}^{*}, S, W, W^{*}, C, C^{*}, P, P^{*}$, $L, L^{*}$. Note that, in the flexible-price equilibrium, $M$ and $M^{*}$ are chosen by home and foreign monetary authorities respectively, $\theta_{f}, \theta_{f}^{*}, \theta_{i}, \theta_{i}^{*}$ are exogenous shocks. In the following, a variable with a tilde represents the value under flexible prices.

The terms of trade at the stage of intermediate-goods production are given by

$$
\widetilde{\tau_{i}}=\frac{P_{F i}}{S P_{H i}^{*}}=\frac{\theta_{i}}{\theta_{i}^{*}} .
$$

At the stage of intermediate-goods production, the terms of trade are determined by relative productivity shocks. In comparison, the terms of trade at the stage of finalgoods production depend on relative productivity shocks at both stages, which are given by

$$
\tilde{\tau_{f}}=\frac{P_{F f}}{S P_{H f}^{*}}=\frac{\theta_{f}}{\theta_{f}^{*}}\left(\frac{\theta_{i}}{\theta_{i}^{*}}\right)^{\varepsilon-\varepsilon^{*}} .
$$

Using optimal flexible prices, the first-order conditions for home and foreign optimal labor supply, the risk-sharing condition, we can express home CPI price index as

$$
\widetilde{P}=\widehat{\lambda \phi}\left(\frac{1}{\theta_{f}}\right)^{n}\left(\frac{1}{\theta_{f}^{*}}\right)^{1-n}\left(\frac{1}{\theta_{i}}\right)^{n \varepsilon+(1-n) \varepsilon^{*}}\left(\frac{1}{\theta_{i}^{*}}\right)^{n(1-\varepsilon)+(1-n)\left(1-\varepsilon^{*}\right)} \widetilde{W},
$$

in which $\widehat{\lambda} \equiv \frac{\lambda}{\lambda-1}, \widehat{\phi} \equiv \frac{\phi}{\phi-1}$.

Substituting the expression for $\widetilde{P}$ into the first-order condition for home labor supply then reducing the resulting equation, we can obtain home consumption, which is given by

$$
\widetilde{C}=(\eta \widehat{\lambda \phi \phi})^{-1} \theta_{f}^{n} \theta_{f}^{* 1-n} \theta_{i}^{n \varepsilon+(1-n) \varepsilon^{*}} \theta_{i}^{* n(1-\varepsilon)+(1-n)\left(1-\varepsilon^{*}\right)} .
$$

Foreign consumption can be derived similarly and is given by

$$
\widetilde{C}^{*}=(\eta \widehat{\lambda} \hat{\phi})^{-1} \theta_{f}^{n^{*}} \theta_{f}^{* 1-n^{*}} \theta_{i}^{n^{*} \varepsilon+\left(1-n^{*}\right) \varepsilon^{*}} \theta_{i}^{* n^{*}(1-\varepsilon)+\left(1-n^{*}\right)\left(1-\varepsilon^{*}\right)} .
$$

Thus, both home and foreign consumption functions are a geometric weighted average of productivity shocks.

Using home market-clearing condition (6), optimal flexible prices, the risk-sharing condition, we can express home employment as

$$
\widetilde{L}=(\eta \widehat{\lambda} \hat{\phi})^{-1}\left[\varepsilon\left(n+n^{*}\right)+\varepsilon^{*}\left(2-n-n^{*}\right)\right] .
$$

Similarly, we can express foreign employment as

$$
\widetilde{L}^{*}=(\eta \widehat{\lambda \phi})^{-1}\left[(1-\varepsilon)\left(n+n^{*}\right)+\left(1-\varepsilon^{*}\right)\left(2-n-n^{*}\right)\right] .
$$

Notice that monetary policy is neutral with respect to the real variables. When $n=n^{*}$, as in Devereux and Engel (2003), consumption is equalized across countries. As a comparison, when $n \neq n^{*}$, a shock has different effects on home and foreign consumption. This implies that, in LCP case, home and foreign monetary responses 
to a shock may be different. Thus, the optimal nominal exchange rate varies to ensure that the risk-sharing condition holds.

\section{Optimal Monetary Policy Rules}

Now we analyze the sticky-price equilibrium and derive optimal monetary policy rules in both PCP and LCP cases. In our model, monetary policy can influence households' expected consumption by affecting pre-set price levels. Following Devereux and Engel (2003), we assume that monetary authorities set monetary policy rules with commitment. Specifically, optimal monetary policy rules are log-linear function of global productivity shocks and given by

$$
\begin{aligned}
& m=a_{1} u+a_{2} u^{*}+a_{3} v+a_{4} v^{*}, \\
& m^{*}=b_{1} u+b_{2} u^{*}+b_{3} v+b_{4} v^{*},
\end{aligned}
$$

in which $m=\ln M$. Hereafter, we use a lower-case letter to denote logarithmic value of a variable.

\subsection{Producer-currency pricing}

From home and foreign money demand equations, the risk-sharing condition, we have

$$
s-E s=(m-E m)-\left(m^{*}-E m^{*}\right),
$$

which implies that the exchange rate will depreciate when home monetary authority issues more money than its foreign counterpart.

From home money demand equation and using the fact that both $P_{H f}$ and $P_{F f}^{*}$ are predetermined, we can obtain

$$
c-E c=(m-E m)-(1-n)(s-E s) .
$$

When the depreciation of home currency occurs, home CPI price level rises. Given nominal money balances held by home households, the consumption will decline. Evidently, the magnitude of the effect of the depreciation of home currency on home households' consumption is governed by the expenditure share on imported final consumption goods.

Similarly, we can get (17)'s foreign counterpart, it is

$$
c^{*}-E c^{*}=\left(m^{*}-E m^{*}\right)+n^{*}(s-E s) .
$$

The depreciation of home currency implies the appreciation of foreign currency, which increases the purchasing power of a certain amount of nominal money balances held by foreign households. As a result, foreign households' consumption increases. 
When playing the Nash game, monetary authority in each country maximizes the expected utility of its own country's households. Following the literature, ${ }^{12}$ we assume that $\chi$ is not too large, in other words, the derived utility from real balances is small as a share of total utility. ${ }^{13}$ Thus, we only focus on the nonmonetary components of the households' utility and solve for the expected utility derived from consumption and employment.

From home market-clearing condition (6), home labor supply equation (4) and its foreign counterpart, the risk-sharing condition (5), home expected employment can be expressed as

$$
E L=(\eta \widehat{\lambda \phi})^{-1}\left[n \varepsilon+n^{*} \varepsilon+(1-n) \varepsilon^{*}+\left(1-n^{*}\right) \varepsilon^{*}\right] .
$$

Due to vertical production and trade structure, home intermediate goods are used as inputs by both home and foreign final-goods producers. From Eq. 19, we know $(\widehat{\lambda \phi})^{-1}\left(n \varepsilon+n^{*} \varepsilon\right)$ is the disutility incurred by producing home intermediate goods which then are used as inputs by home final-goods producers, $(\widehat{\lambda \phi})^{-1}\left[(1-n) \varepsilon^{*}+\left(1-n^{*}\right) \varepsilon^{*}\right]$ is the disutility incurred by producing home intermediate goods which are used as inputs by foreign final-goods producers.

From home CPI price index (1), home labor supply equation (4) and its foreign counterpart, the risk-sharing condition (5), we can obtain the following equation

$$
1=(\eta \widehat{\lambda} \hat{\phi})\left[E\left(\frac{S^{1-n} C}{\theta_{f} \theta_{i}^{\varepsilon} \theta_{i}^{* 1-\varepsilon}}\right)\right]^{n}\left[E\left(\frac{S^{-n} C}{\theta_{f}^{*} \theta_{i}^{\varepsilon^{*}} \theta_{i}^{* 1-\varepsilon^{*}}}\right)\right]^{1-n} .
$$

Since the exogenous shocks have a jointly lognormal distribution, all endogenous variables are lognormal as well. Therefore, we can use the previous equation and express home expected utility from consumption as

$$
\begin{aligned}
E c= & -\ln (\eta \widehat{\lambda} \hat{\phi})-\frac{n(1-n) \sigma_{s}^{2}}{2}-\frac{\sigma_{c}^{2}}{2}+n(1-n)\left(\sigma_{s u}-\sigma_{s u^{*}}\right) \\
& +n(1-n)\left(\varepsilon-\varepsilon^{*}\right)\left(\sigma_{s v}-\sigma_{s v^{*}}\right)+n \sigma_{c u}+(1-n) \sigma_{c u^{*}} \\
& +\left(n \varepsilon+(1-n) \varepsilon^{*}\right) \sigma_{c v}+\left(n(1-\varepsilon)+(1-n)\left(1-\varepsilon^{*}\right)\right) \sigma_{c v^{*}} \\
& -\frac{n \sigma_{u}^{2}+(1-n) \sigma_{u^{*}}^{2}-\frac{\left(n \varepsilon^{2}+(1-n) \varepsilon^{* 2}\right) \sigma_{v}^{2}}{2}-n \varepsilon \sigma_{u v}}{2} \\
& -\frac{\left(n(1-\varepsilon)^{2}+(1-n)\left(1-\varepsilon^{*}\right)^{2}\right) \sigma_{v^{*}}^{2}}{2}-(1-n)\left(1-\varepsilon^{*}\right) \sigma_{u^{*} v^{*}}
\end{aligned}
$$

From Eqs. 16, 17 and 21, we observe that, in PCP case, both home and foreign monetary policy rules can influence home consumption. The same claim also applies to foreign consumption.

\footnotetext{
${ }^{12}$ See, among many others, Obstfeld and Rogoff (1995, 2000, 2002), Corsetti and Pesenti (2001, 2005), Devereux and Engel (2003), Benigno and Benigno (2003), Devereux et al. (2007), Shi and Xu (2007), Wang and Zou $(2013,2015)$.

${ }^{13}$ For empirical evidence, see Cooley and Hansen (1989).
} 
Thus we can obtain the expected utility of the home representative household, it is $E U=E c-\eta E L$. Similarly, we can get its foreign analog. From Eqs. 1418 , the variance and covariance terms in the expressions for $E U$ and $E U^{*}$ can be expressed as the functions of $a=\left\{a_{1}, a_{2}, a_{3}, a_{4}\right\}, b=\left\{b_{1}, b_{2}, b_{3}, b_{4}\right\}$ and the exogenous variances and covariances. In a Nash game, each of the monetary authorities chooses the parameters of its monetary policy rule to maximize the expected utility of its own country's representative household, taking its counterpart's actions as given. Specifically, home and foreign monetary policy makers play the following Nash game

$$
\max _{a} E U\left(a, b^{N}\right) \quad \max _{b} E U^{*}\left(a^{N}, b\right)
$$

The solution to Eq. P1 is given by proposition 1 .

Proposition 1 The solution to problem (P1) is

$$
\begin{aligned}
& a_{1}^{N}=1, a_{2}^{N}=0, a_{3}^{N}=\varepsilon, a_{4}^{N}=1-\varepsilon, \\
& b_{1}^{N}=0, b_{2}^{N}=1, b_{3}^{N}=\varepsilon^{*}, b_{4}^{N}=1-\varepsilon^{*} .
\end{aligned}
$$

Proof See Appendix. ${ }^{14}$

Inspection of Proposition 1 indicates that optimal monetary responses to shocks at the stage of final-goods production are the same as those in Obstfeld and Rogoff (2002), and Devereux and Engel (2003). Different from optimal monetary responses to shocks at the stage of final-goods production, both home and foreign monetary authorities respond to shocks at the stage of intermediate-goods production. Why? When a home productivity shock at the stage of intermediate-goods production occurs, home intermediate-goods producers tend to set a lower price than before. Due to vertical production and trade structure, both home and foreign final-goods producers substitute intermediate goods produced in the home country for those produced in the foreign country.

The point can be seen clearly from the demand functions of final-goods producers in both countries for intermediate goods. The demand function of home final-goods producers for home intermediate good $j_{i}$ is

$$
\begin{aligned}
Y_{H i}\left(j_{i}\right) & \equiv \int_{0}^{1} Y_{H i}\left(j_{f}, j_{i}\right) d j_{f}=\varepsilon\left(\frac{P_{H i}}{C\left(P_{H i}, P_{F i}\right)}\right)^{-1}\left[n \frac{P C}{P_{H f}}+n^{*} \frac{P^{*} C^{*}}{P_{H f}^{*}}\right] \\
& =\varepsilon \theta_{f}^{-1}\left(\frac{\theta_{i}}{\theta_{i}^{*}}\right)^{1-\varepsilon}\left[n\left(\frac{S P_{F f}^{*}}{P_{H f}}\right)^{1-n} C+n^{*}\left(\frac{S P_{F f}^{*}}{P_{H f}}\right)^{1-n^{*}} C^{*}\right] .
\end{aligned}
$$

When $\theta_{i}$ rises, from the expression for $P_{H i}$ given in Table 1, we know that the price of home intermediate goods decreases. Thus, home final-goods producers increase

\footnotetext{
${ }^{14}$ Which is available upon request.
} 
their demands for home intermediate goods. The demand function of home finalgoods producers for foreign intermediate $\operatorname{good} j_{i}^{*}$ is

$$
\begin{aligned}
Y_{F i}\left(j_{i}^{*}\right) & \equiv \int_{0}^{1} Y_{F i}\left(j_{f}, j_{i}^{*}\right) d j_{f}=(1-\varepsilon)\left(\frac{P_{F i}}{C\left(P_{H i}, P_{F i}\right)}\right)^{-1}\left[n \frac{P C}{P_{H f}}+n^{*} \frac{P^{*} C^{*}}{P_{H f}^{*}}\right] \\
& =(1-\varepsilon) \theta_{f}^{-1}\left(\frac{\theta_{i}^{*}}{\theta_{i}}\right)^{\varepsilon}\left[n\left(\frac{S P_{F f}^{*}}{P_{H f}}\right)^{1-n} C+n^{*}\left(\frac{S P_{F f}^{*}}{P_{H f}}\right)^{1-n^{*}} C^{*}\right] .
\end{aligned}
$$

When the price of home intermediate goods decreases, comparatively, foreign intermediate goods become more expressive, home final-goods producers lower their demands for foreign intermediate goods. The situation facing foreign final-goods producers is similar, both of them substitute cheaper home intermediate goods for more expensive foreign intermediate goods. ${ }^{15}$

This implies a negative demand shock to foreign intermediate-goods producers. In order to counteract the adverse effect, foreign monetary authority expands money supply to increase the final-goods demands of it own country's households. To meet the increased demands, foreign final-goods producers increase intermediate-goods inputs produced in their own country. In the presence of vertical production and trade structure, home final-goods producers also increase foreign intermediate-goods inputs. However, foreign monetary authority's expansionary response depreciates its own currency, by the expenditure-switching mechanism of the exchange rate, the home country's final-goods sector is adversely affected. Therefore, home monetary authority also expands the money supply to counteract the adverse effect.

In Devereux and Engel (2003), optimal monetary policy in PCP case can replicate the flexible price allocation. By comparison, in Shi and $\mathrm{Xu}$ (2007), optimal monetary policy in PCP case can not achieve the flexible price allocation when vertical production and trade is introduced and prices at both stages are sticky.

${ }^{15}$ The demand function of foreign final-goods producers for home intermediate good $j_{i}$ is

$$
\begin{aligned}
Y_{H i}^{*}\left(j_{i}\right) & \equiv \int_{0}^{1} Y_{H i}^{*}\left(j_{f}^{*}, j_{i}\right) d j_{f}^{*}=\varepsilon^{*}\left(\frac{P_{H i}^{*}}{C^{*}\left(P_{H i}^{*}, P_{F i}^{*}\right)}\right)^{-1}\left[(1-n) \frac{P C}{P_{F f}}+\left(1-n^{*}\right) \frac{P^{*} C^{*}}{P_{F f}^{*}}\right] \\
& =\varepsilon^{*} \theta_{f}^{*-1}\left(\frac{\theta_{i}}{\theta_{i}^{*}}\right)^{1-\varepsilon^{*}}\left[(1-n)\left(\frac{P_{H f}}{S P_{F f}^{*}}\right)^{n} C+\left(1-n^{*}\right)\left(\frac{P_{H f}}{S P_{F f}^{*}}\right)^{n^{*}} C^{*}\right] .
\end{aligned}
$$

As a comparison, the demand function of foreign final-goods producers for their own country's intermediate $\operatorname{good} j_{i}^{*}$ is

$$
\begin{aligned}
Y_{F i}^{*}\left(j_{i}^{*}\right) & \equiv \int_{0}^{1} Y_{F i}^{*}\left(j_{f}^{*}, j_{i}^{*}\right) d j_{f}^{*}=\left(1-\varepsilon^{*}\right)\left(\frac{P_{F i}^{*}}{C^{*}\left(P_{H i}^{*}, P_{F i}^{*}\right)}\right)^{-1}\left[(1-n) \frac{P C}{P_{F f}}+\left(1-n^{*}\right) \frac{P^{*} C^{*}}{P_{F f}^{*}}\right] \\
& =\left(1-\varepsilon^{*}\right) \theta_{f}^{*-1}\left(\frac{\theta_{i}^{*}}{\theta_{i}}\right)^{\varepsilon^{*}}\left[(1-n)\left(\frac{P_{H f}}{S P_{F f}^{*}}\right)^{n} C+\left(1-n^{*}\right)\left(\frac{P_{H f}}{S P_{F f}^{*}}\right)^{n^{*}} C^{*}\right] .
\end{aligned}
$$


The reason is, unlike the model with one stage of production and trade, optimal monetary policy in Shi and $\mathrm{Xu}$ (2007) can not bring the terms of trade at the stage of final-goods production and those at the stage of intermediate-goods production to efficient levels simultaneously. In our model, it seems to be reasonable to conclude that optimal monetary policy can replicate the flexible price allocation when prices at the stage of intermediate-goods production are flexible.

Proposition 2 The optimal monetary policy requires the exchange rate to be flexible, and it can replicate the flexible price allocation.

\section{Proof See Appendix.}

When prices at the stage of intermediate-goods production are flexible, it is certain that the terms of trade at the stage of intermediate-goods production are efficient. Thus, the optimal exchange-rate policy is to mimic the efficient terms of trade at the stage of final-goods production. From Eqs. 14-16 and Proposition 1, we know that $S=\frac{\theta_{f}}{\theta_{f}^{*}}\left(\frac{\theta_{i}}{\theta_{i}^{*}}\right)^{\varepsilon-\varepsilon^{*}}$, thus the nominal exchange rate is flexible. In addition, we can prove that the nominal exchange rate can perfectly replicate the terms of trade at the stage of final-goods production. ${ }^{16}$ Thus, like Devereux and Engel (2003), the optimal monetary policy in PCP case can replicate the flexible price allocation.

\subsection{Local-currency pricing}

In LCP case, final-goods prices facing home households are predetermined and set in the home currency. Thus, from home money demand equation, we can obtain

$$
c-E c=(m-E m) .
$$

Similarly, we have

$$
c^{*}-E c^{*}=\left(m^{*}-E m^{*}\right) .
$$

Observing equation (22), we know that, in LCP case, home consumption is not affected by foreign monetary policy. The reason is that the pass-through of the exchange rate is zero and the expenditure-switching function of the exchange rate does not work in LCP case. Likewise, foreign consumption is independent of home monetary policy.

Expected employment of the home households in LCP case is identical to its analog in PCP case. Now we solve for home households' expected utility from consumption.

\footnotetext{
${ }^{16} \mathrm{In}$ PCP case, the terms of trade at the stage of final-goods production can be expressed as: $\tau_{f}=\frac{P_{F f}}{S P_{H f}^{*}}=$ $\frac{\widehat{\lambda} S E\left(\frac{P_{H i}^{* \varepsilon^{*}} P_{F i}^{* 1-\varepsilon^{*}}}{\theta_{f}^{*}}\right)}{\widehat{\lambda} E\left(\frac{P_{H i}^{\varepsilon} P_{F i}^{1-\varepsilon}}{\theta_{f}}\right)}=\frac{S E\left(\frac{W^{*}}{\theta_{f}^{*} \theta_{i}^{\varepsilon^{*}} \theta_{i}^{* 1-\varepsilon^{*}}}\right)}{E\left(\frac{S W^{*}}{\theta_{f} \theta_{i}^{\varepsilon} \theta_{i}^{* 1-\varepsilon}}\right)}$, using the expression $S=\frac{\theta_{f}}{\theta_{f}^{*}}\left(\frac{\theta_{i}}{\theta_{i}^{*}}\right)^{\varepsilon-\varepsilon^{*}}$, we can get $\tau_{f}=S$.
} 
From home CPI price index (1), home labor supply equation (4) and its foreign counterpart, the risk-sharing condition (5), we have the following equation

$$
1=\eta \widehat{\lambda} \widehat{\phi}\left[E\left(\frac{C}{\theta_{f} \theta_{i}^{\varepsilon} \theta_{i}^{* 1-\varepsilon}}\right)\right]^{n}\left[E\left(\frac{C}{\theta_{f}^{*} \theta_{i}^{\varepsilon^{*}} \theta_{i}^{* 1-\varepsilon^{*}}}\right)\right]^{1-n} .
$$

From Eq. 24 and the properties of lognormal random variables, we can express home households' expected utility form consumption as

$$
\begin{aligned}
E c= & -\ln (\eta \widehat{\lambda \hat{\phi}})-\frac{\sigma_{c}^{2}}{2}+n \sigma_{c u}+(1-n) \sigma_{c u^{*}}+\left(n \varepsilon+(1-n) \varepsilon^{*}\right) \sigma_{c v} \\
& +\left(n(1-\varepsilon)+(1-n)\left(1-\varepsilon^{*}\right)\right) \sigma_{c v^{*}}-n \varepsilon \sigma_{u v}-(1-n)\left(1-\varepsilon^{*}\right) \sigma_{u^{*} v^{*}} \\
& -\frac{n \sigma_{u}^{2}+(1-n) \sigma_{u^{*}}^{2}}{2}-\frac{\left(n(1-\varepsilon)^{2}+(1-n)\left(1-\varepsilon^{*}\right)^{2}\right) \sigma_{v^{*}}^{2}}{2} \\
& -\frac{\left(n \varepsilon^{2}+(1-n) \varepsilon^{* 2}\right) \sigma_{v}^{2}}{2}
\end{aligned}
$$

In LCP case, home CPI index is insulated from the volatility of the nominal exchange rate. As a result, foreign monetary policy can not affect the mean and variance of home consumption, which is verified by Eqs. 22 and 25.

As in PCP case, we can obtain the expected utility of the home representative household, it is $E U=E c-\eta E L$. Similarly, we can get its foreign analog. From Eqs. 14, 15, 22, 23, the variance and covariance terms in the expressions for $E U$ and $E U^{*}$ can be expressed as the functions of $a=\left\{a_{1}, a_{2}, a_{3}, a_{4}\right\}, b=\left\{b_{1}, b_{2}, b_{3}, b_{4}\right\}$ and the exogenous variances and covariances. The Nash game in LCP case can be described similarly as

$$
\max _{a} E U\left(a, b^{N}\right) \quad \max _{b} E U^{*}\left(a^{N}, b\right)
$$

The solution to Eq. P2 is given by proposition 3 .

Proposition 3 The solution to problem $(\mathrm{P} 2)$ is

$$
\begin{aligned}
& a_{1}^{N}=n, a_{2}^{N}=1-n, a_{3}^{N}=n \varepsilon+(1-n) \varepsilon^{*}, a_{4}^{N}=n(1-\varepsilon)+(1-n)\left(1-\varepsilon^{*}\right), \\
& b_{1}^{N}=n^{*}, b_{2}^{N}=1-n^{*}, b_{3}^{N}=n^{*} \varepsilon+\left(1-n^{*}\right) \varepsilon^{*}, b_{4}^{N}=n^{*}(1-\varepsilon)+\left(1-n^{*}\right)\left(1-\varepsilon^{*}\right) .
\end{aligned}
$$

\section{Proof See Appendix.}

When productivity shocks at the stage of intermediate-goods production occur, both home and foreign monetary authorities expand money supply. The reason is similar to what we have analyzed in PCP case. Different from optimal monetary responses in PCP case, in LCP case, both home and foreign monetary authorities need to respond to a positive productivity shock at the stage of final-goods production with expansionary money supply no matter where the shock occurs. Why? When both local and exporting prices are predetermined, the demands for home final goods by local and foreign households are constant even if home final-goods producers' 
potential to supply increases after a positive home productivity shock at the stage of final-goods production occurs. Thus the best response of home final-goods producers is to lower the inputs produced by both home and foreign intermediate-goods producers. As a result, the shock acts as a negative labor demand shock in both home and foreign countries. The reasoning derives from our observation of home and foreign labor demand functions. Home labor demand function is

$$
\begin{aligned}
L= & \varepsilon \frac{C\left(P_{H i}, P_{F i}\right)}{\theta_{i} P_{H i}}\left(n \frac{P C}{P_{H f}}+n^{*} \frac{P^{*} C^{*}}{P_{H f}^{*}}\right)+\varepsilon^{*} \frac{C^{*}\left(P_{H i}^{*}, P_{F i}^{*}\right)}{\theta_{i} P_{H i}^{*}}\left((1-n) \frac{P C}{P_{F f}}+\left(1-n^{*}\right) \frac{P^{*} C^{*}}{P_{F f}^{*}}\right) \\
= & \varepsilon\left(\theta_{f} \theta_{i}\right)^{-1}\left(\frac{\theta_{i}}{\theta_{i}^{*}}\right)^{1-\varepsilon}\left[n\left(\frac{P_{F f}}{P_{H f}}\right)^{1-n} C+n^{*}\left(\frac{P_{F f}^{*}}{P_{H f}^{*}}\right)^{1-n^{*}} C^{*}\right] \\
& +\varepsilon^{*}\left(\theta_{f}^{*} \theta_{i}\right)^{-1}\left(\frac{\theta_{i}}{\theta_{i}^{*}}\right)^{1-\varepsilon^{*}}\left[(1-n)\left(\frac{P_{H f}}{P_{F f}}\right)^{n} C+\left(1-n^{*}\right)\left(\frac{P_{H f}^{*}}{P_{F f}^{*}}\right)^{n^{*}} C^{*}\right] .
\end{aligned}
$$

Foreign labor demand function is expressed as

$$
\begin{aligned}
L^{*}= & (1-\varepsilon) \frac{C\left(P_{H i}, P_{F i}\right)}{\theta_{i}^{*} P_{F i}}\left(n \frac{P C}{P_{H f}}+n^{*} \frac{P^{*} C^{*}}{P_{H f}^{*}}\right) \\
& +\left(1-\varepsilon^{*}\right) \frac{C^{*}\left(P_{H i}^{*}, P_{F i}^{*}\right)}{\theta_{i}^{*} P_{F i}^{*}}\left((1-n) \frac{P C}{P_{F f}}+\left(1-n^{*}\right) \frac{P^{*} C^{*}}{P_{F f}^{*}}\right) \\
= & (1-\varepsilon)\left(\theta_{f} \theta_{i}^{*}\right)^{-1}\left(\frac{\theta_{i}^{*}}{\theta_{i}}\right)^{\varepsilon}\left[n\left(\frac{P_{F f}}{P_{H f}}\right)^{1-n} C+n^{*}\left(\frac{P_{F f}^{*}}{P_{H f}^{*}}\right)^{1-n^{*}} C^{*}\right] \\
& +\left(1-\varepsilon^{*}\right)\left(\theta_{f}^{*} \theta_{i}^{*}\right)^{-1}\left(\frac{\theta_{i}^{*}}{\theta_{i}}\right)^{\varepsilon^{*}}\left[(1-n)\left(\frac{P_{H f}}{P_{F f}}\right)^{n} C+\left(1-n^{*}\right)\left(\frac{P_{H f}^{*}}{P_{F f}^{*}}\right)^{n^{*}} C^{*}\right] .
\end{aligned}
$$

Evidently, when $\theta_{f}$ rises, both home and foreign intermediate-goods producers lower their demands for labor. The decrease in wage in both countries depresses the consumption and sets a deflated cycle in motion. In order to avoid such a situation, both home and foreign monetary authorities' optimal responses to a positive home productivity shock at the stage of final-goods production must be expansionary.

When the degrees of home bias in consumption are equalized between home and foreign households, Devereux and Engel (2003) conclude that both home and foreign monetary authorities respond identically to a productivity shock in LCP case, regardless of the place where it originates from. Thus optimal monetary policy rules ensure the equalization of consumption between two countries. As a result, the exchange rate does not need to move and the risk-sharing condition is satisfied. In our model, when we consider the case in which the degrees of home bias in consumption are not equalized between home and foreign households. As shown in Proposition 3, home monetary authority's response to a productivity shock is different from its foreign 
counterpart's response. It means that the consumption is not identical across countries. Thus, it leaves room for the movement of the nominal exchange rate to ensure perfect risk sharing between two countries. To be specific, we have

\section{Proposition 4}

(1). When the degrees of home bias in consumption are not identical between two countries, optimal monetary policy produces a flexible nominal exchange rate.

(2). When the degrees of home bias in consumption are identical between two countries, optimal monetary policy produces a fixed nominal exchange rate.

\section{Proof}

(1). From Eq. 14 and Proposition 3, we can obtain

$$
M=\theta_{f}^{n} \theta_{f}^{* 1-n} \theta_{i}^{n \varepsilon+(1-n) \varepsilon^{*}} \theta_{i}^{* n(1-\varepsilon)+(1-n)\left(1-\varepsilon^{*}\right)} .
$$

Similarly, we have

$$
M^{*}=\theta_{f}^{n^{*}} \theta_{f}^{* 1-n^{*}} \theta_{i}^{n^{*} \varepsilon+\left(1-n^{*}\right) \varepsilon^{*}} \theta_{i}^{* n^{*(1-\varepsilon)+\left(1-n^{*}\right)\left(1-\varepsilon^{*}\right)} .}
$$

Thus, the nominal exchange rate can be expressed as

$$
S=\frac{M}{M^{*}}=\left(\frac{\theta_{f}}{\theta_{f}^{*}}\right)^{n-n^{*}}\left(\frac{\theta_{i}}{\theta_{i}^{*}}\right)^{\left(n-n^{*}\right)\left(\varepsilon-\varepsilon^{*}\right)}
$$

From Eq. 28, we know the nominal exchange rate is flexible when $n \neq n^{*}$.

(2). The conclusion is evident from the inspection of Eq. 28.

In LCP case, all exporting firms set prices in consumers' currency one period in advance. The relative price of foreign final goods in terms of home final goods facing the households in each country is fixed. The terms of trade at the stage of final-goods production in PCP case is just the relative price facing the households. However, in LCP case, the terms of trade at the stage of final-goods production is not equal to the relative price facing the households. Though the relative price facing the households is fixed, the terms of trade at the stage of final-goods production move with the nominal exchange rate. In spite of this fact, they are not efficient. In other words, optimal monetary policy in LCP case can not replicate the terms of trade at the stage of final-goods production in flexible price equilibrium. Accordingly, it is impossible for optimal monetary policy in LCP case to replicate the allocation in the flexible price equilibrium. Specifically, we have

Proposition 5 The optimal monetary policy can not replicate the flexible price allocation. 
Proof See Appendix.

To illustrate that optimal monetary policy involves the flexible nominal exchange rate, we derive home and foreign households' consumption respectively. Home households' consumption is

$$
\begin{gathered}
C=(\eta \widehat{\lambda} \widehat{\phi})^{-1} \exp \left\{-n(1-n)\left(1+\left(\varepsilon-\varepsilon^{*}\right)^{2}\right) \sigma^{2}-2 n(1-n)\left(\varepsilon-\varepsilon^{*}\right) \sigma_{u v}\right\} \\
\theta_{f}^{n} \theta_{f}^{* 1-n} \theta_{i}^{n \varepsilon+(1-n) \varepsilon^{*}} \theta_{i}^{* n(1-\varepsilon)+(1-n)\left(1-\varepsilon^{*}\right)}
\end{gathered}
$$

By comparison, foreign households' consumption is ${ }^{17}$

$$
\begin{aligned}
C^{*}= & (\eta \widehat{\lambda \hat{\phi}})^{-1} \exp \left\{-n^{*}\left(1-n^{*}\right)\left(1+\left(\varepsilon-\varepsilon^{*}\right)^{2}\right) \sigma^{2}-2 n^{*}\left(1-n^{*}\right)\left(\varepsilon-\varepsilon^{*}\right) \sigma_{u v}\right\} \\
& \theta_{f}^{n^{*}} \theta_{f}^{* 1-n^{*}} \theta_{i}^{n^{*} \varepsilon+\left(1-n^{*}\right) \varepsilon^{*}} \theta_{i}^{* n^{*}(1-\varepsilon)+\left(1-n^{*}\right)\left(1-\varepsilon^{*}\right)}
\end{aligned}
$$

As shown in Eqs. 29 and 30, when a productivity shock, regardless of the place where it originates from, occurs, optimal monetary policy does not produce a constant proportion between home and foreign consumption if the degrees of home bias in consumption are not equalized between two countries. However, in order to achieve perfect risk sharing between home and foreign households under the fixed nominal exchange rate, the risk-sharing condition, i.e. Eq. 5, requires a constant proportion between home and foreign consumption. The analysis implies that it is necessary for the nominal exchange rate to be flexible to ensure that perfect risk sharing is satisfied.

Devereux and Engel (2007) find that optimal exchange rate policy is a tradeoff between risk sharing and terms of trade adjustment. When final-goods prices are sticky, but intermediate-goods prices are flexible, in general, they find that the optimal nominal exchange rate is flexible. However, when all intermediate goods are traded and the degrees of home bias in production are identical between home and foreign final-goods producers, the optimal nominal exchange rate is fixed. As a comparison, in our model, even if the degrees of home bias in production are identical between home and foreign final-goods producers $\left(\varepsilon=\varepsilon^{*}\right)$, the optimal nominal exchange rate is still flexible unless the expenditure shares between home and foreign households are identical. Why? In Devereux and Engel (2007), final consumption goods are nontradable, thus the flexibility of intermediate-goods prices can achieve the desired terms of trade adjustment without movements in the exchange rate. Otherwise, any exchange-rate movement would lead to a departure from optimal risk sharing. In our model in which final consumption goods are tradable, though the flexibility of intermediate-goods prices can still achieve the desired terms of trade adjustment at the stage of intermediate-goods production without movements in the exchange rate, a flexible exchange rate is needed to achieve optimal risk sharing when

\footnotetext{
${ }^{17}$ The detailed derivation of Eqs. 29 and 30 is given in the Appendix.
} 
the expenditure shares of the home and foreign households on tradable final goods are different.

\section{Conclusion}

In this paper, we examine optimal exchange-rate flexibility in a model of localcurrency pricing with vertical production and trade. Following a large body of empirical evidence, we assume that final-goods prices are sticky, but intermediategoods prices are flexible. In addition, we assume that the expenditure share of home households on final consumption goods produced in one country is different from that of foreign households. The expenditure share of home final-goods producers on intermediate inputs produced in one country is also assumed to be different from that of foreign final-goods producers.

In order to make a comparison, as in Devereux and Engel (2003), first we analyze the case of PCP. In PCP case, optimal monetary policy involves the flexibility of the nominal exchange rate to replicate the efficient terms of trade at the stage of final-goods production. Thus, when the efficiency of the terms of trade at the stage of intermediate-goods production is guaranteed by the price flexibility at their own stage, optimal monetary policy can replicate the flexible price allocation.

By comparison, in LCP case, optimal monetary policy can not replicate the terms of trade at the stage of final-goods production. Thus, though the terms of trade at the stage of intermediate-goods production are still efficient, it is impossible for optimal monetary policy to replicate the allocation in the flexible price equilibrium. In addition, when the degrees of home bias in consumption are not equalized between two countries, after a productivity shock, regardless of where it originates from, occurs, optimal monetary policy can not equalize home consumption with foreign consumption. Accordingly, unlike in Devereux and Engel (2003), in order to achieve perfect risk sharing between home and foreign households, it is necessary for the nominal exchange rate to be flexible.

We also find that, when final consumption goods are allowed to be sold in world markets, Devereux and Engel (2007)s conclusion needs to be modified. When finalgoods prices are sticky, but intermediate-goods prices are flexible, they find that the optimal nominal exchange rate is fixed when all intermediate goods are traded and the degrees of home bias in production are identical between home and foreign final-goods producers. As a comparison, we find that, under the same condition, the optimal nominal exchange rate is flexible if the degrees of home bias are not the same between home and foreign households.

Acknowledgments We thank the editor, George S. Tavlas, and an anonymous referee for very insightful comments. For helpful discussions, we thank Xiaoyong Cui, Wei Wang, Hongfu Ni, Dongzhou Mei, Xingchun Wen, Fuyang Zhao, Liyun Wu, Dongling Wu, and seminar participants of Macro Group at GSM. The corresponding author acknowledges financial support from China Postdoctoral Science Foundation, Grant Number 2014M560832. He is also grateful to Jiechang Xia, Dingsheng Zhang, Xiongjian Wang, Xiuhong Shi, Lili Yan, Feng shi for their help. 


\section{References}

Atkeson A, Burstein A (2008) Pricing to market, trade cost, and international relative prices. Am Econ Rev 98(5):1998-2031

Benigno G, Benigno P (2003) Price stability in open economies. Rev Econ Stud 70(4):743-764

Betts C, Devereux MB (2000) Exchange rate dynamics in a model of pricing-to-market. J Int Econ 50:215244

Bils M, Klenow P (2004) Some evidence on the importance of sticky prices. J Polit Econ 112:947-985

Bridgman B (2012) The rise of vertical specialization trade. J Int Econ 86:133-140

Clark T (1999) The responses of prices at different stages of production to monetary policy shocks. Rev Econ Stat 81:420-433

Cooley TF, Hansen GD (1989) The inflation tax in a real business cycle model. Am Econ Rev 79(4):733748

Corsetti G, Pesenti P (2001) Welfare and macroeconomic interdependence. Q J Econ 116(2):421-446

Corsetti G, Pesenti P (2005) International dimensions of optimal monetary policy. J Monet Econ 52:281305

Devereux MB, Engel C (2003) Monetary policy in the open economy revisited: price setting and exchange rate flexibility. Rev Econ Stud 70:765-783

Devereux MB, Engel C (2007) Expending switching versus real exchange rate stabilization: competing objectives for exchange rate policy. J Monet Econ 54:2346-2374

Devereux MB, Shi K, Xu JY (2005) Friedman redux: Restricting monetary policy rules to support flexible exchange rates. Econ Lett 87:291-299

Devereux MB, Shi K, Xu JY (2007) Global monetary policy under a dollar standard. J Int Econ 71:113132

Duarte M, Obstfeld M (2008) Monetary policy in the open economy revisited: The case for exchange-rate flexibility restored. J Int Money Finance 27:949-957

Engel C (1999) Accounting for U.S. real exchange rate changes. J Polit Econ 107:507-538

Engel C (2011) Currency misalignments and optimal monetary policy: a reexamination. Am Econ Rev 101:2796-2822

Feenstra RC (1998) Integration of trade and disintegration of production in the global economy. J Econ Perspect 12:31-50

Friedman M (1953) The case for flexible exchange rates. In: Essays in Positive Economics. University of Chicago Press, pp 157-203

Gong LT, Wang C, Zou HF (2016) Optimal monetary policy with international trade in intermediate inputs. J Int Money Financ 65:140-165

Hummels D, Ishii J, Yi KM (2001) The nature and growth of vertical specialization in world trade. J Int Econ 54:75-96

Hummels D, Rapoport D, Yi KM (1998) Vertical specialization and the changing nature of world trade. Econ Policy Rev 4:79-99

Johnson RC (2014) Trade in intermediate inputs and business cycle comovement. Am Econ J Macroecon 6(4):39-83

Murphy KM, Shleifer A, Vishny RW (1989) Building blocks of market clearing business cycle models. NBER Macroecon Annu 4:247-287

Nakamura E, Steinsson J (2008) Five facts about prices: a reevaluation of menu cost models. Q J Econ 123:1415-1464

Obstfeld M, Rogoff K (1995) Exchange rate dynamics redux. J Polit Econ 103:624-660

Obstfeld M, Rogoff K (2000) New directions for stochastic open economy models. J Int Econ 50:117-153

Obstfeld M, Rogoff K (2002) Global implications of self-oriented national monetary policy. Q J Econ 117(2):503-535

Pang K, Tang Y (2014) Vertical trade, exchange rate pass-through, and the exchange rate regimes. Open Econ Rev 25:477-520

Senay O, Sutherland A (2015) Local currency pricing, foreign monetary shocks, and exchange rate policy. Open Econ Rev 26:633-661 
Shi K, Xu JY (2007) Optimal monetary policy with vertical production and trade. Rev Int Econ 15: $514-537$

Wang C, Zou HF (2013) On the efficiency of monetary and fiscal policy in open economies. Ann Econ Financ 14:179-206

Wang C, Zou HF (2015) Optimal monetary policy under a global dollar standard: the effect of vertical trade and production. Open Econ Rev 26:121-137

Tavlas GS (2015) In old Chicago: simons, Friedman, and the development of monetary-policy rules. J Money Credit Bank 47(1):99-121

Yi KM (2003) Can vertical specialization explain the growth of world trade. J Polit Econ 111:52-102

Yi KM (2010) Can multistage production explain the home bias in trade. Am Econ Rev 100:364-393 